Vol.1 No.3. Oktober 2018. pp.1-13. Copyright@2018 PUBLICUHO Faculty of Social and Political Sciences Halu Oleo University, Kendari, Southeast Sulawesi, Indonesia. ISSN: 2460-058X | e-ISSN: 2621-1351. Open Access at: http://ojs.uho.ac.id/index.php/PUBLICUHO

Jounal publiuho is licensed under a Creative Commons Attribution 4.0 International License, which permits unrestricted use, distribution, and reproduction in any medium, provided the original work is properly cited.

\title{
ANALISIS RESTRUKTURISASI BIROKRASI DALAM PENGEMBANGAN GOOD GOVERNANCE PADA SEKERTARIAT DAERAH KABUPATEN KONAWE UTARA

\author{
Oleh: \\ Bakti ${ }^{1}$, La Ode Muhammad Elwan ${ }^{2}$ \\ 1,2 Dosen Fakultas Ilmu Sosial dan Ilmu Politik Universitas Halu Oleo \\ bakti.pascasarjana@gmail.com, muh.elwan@uho.ac.id
}

\begin{abstract}
The problem of this research is : (1) How restructure of bureaucracy supports good governance at secretary of local government North konawe regency. (2) How restructure of bureaucracy that implemented by secretary of local government north konawe regency creates good governance.

The aim of this research is : (1) To analyze how restructure of bureaucracy at secretary of local government north konawe regency supports good governance. (2) To know how restructure that carried out by secretary of local government north konawe regency in supporting good governance.

This research is a study case, the population of this research is all head of division, at secretary of local government north konawe regency and taking totally sampling, data is collected by interview, observation, and documentation to all respondents and inform men . data is processed by descriptive qualitative.

The result of the research shows that (1) Implementation of restructure of bureaucracy in supporting good governance at secretary of local government north konawe regency has generally been carried out and met their needs to organization dynamic. (2) Implementation of restructure of bureaucracy toward good governance at secretary of local government north konawe regency.

Based on the result of research can be concluded that restructure of bureaucracy at secretary of local government north konawe regency has been better carried our, because of all resources potency has been optimally maximize.
\end{abstract}

\section{Keywords : Bureaucratic restructuring, Good Governance}

\section{PENDAHULUAN}

Refleksi perjuangan bangsa Indonesia banyak menyisakan peristiwa yang telah dilakukan dalam rangka perubahan ke arah yang lebih baik, ini tentunya akan memberikan semangat dengan terjadinya beberapa pergeseran nilai yang telah di tata dalam rangka melahirkan format baru dalam tatakelola pemerintahan yang baik.

Kesejahteraan rakyat akan terwujud dengan baik apabila rakyat memiliki keleluasaan untuk menentukan nasibnya sendiri dan memiliki akses serta ruang yang cukup untuk masuk dalam arena proses pengambilan kebijakan publik. Adanya ruang yang cukup bagi rakyat untuk ikut mempengaruhi proses pengambilan kebijakan publik yang akan sangat menentukan nasibnya hanya mungkin tercipta jika ada Demokratisasi. Dalam sistem baru yang dianut oleh Undang-Undang Nomor 32 Tahun 2004 tersebut, sistemnya dirubah secara total yaitu menempatkan rakyat lebih dominan dalam menentukan arah dan tujuan pembangunan khususnya dalam konteks penyelenggaraan Otonomi Daerah. Dalam pelaksanaan Otonomi Daerah antara Birokrasi dan Rakyat berada dalam ruang dan waktu yang sama sehingga berlaku "Teori Zero Sum Game", penguatan pada sisi Birokrasi berarti pelemahan pada sisi rakyat dan begitu pula sebaliknya. 
Kontek Otonomi Daerah yang dilaksanakan di daerah, apakah semangat yang dikandung oleh Undang Undang No 32 Tahun 2004 tentang Pemerintahan Daerah beserta peraturan derivasinya yaitu dalam bentuk Peraturan Pemerintah yang ingin mewujudkan penguatan pada sisi rakyat dan mengurangi dominasi birokrasi benar diimplementasikan oleh Pemerintah Daerah. Untuk itu apakah Pemerintah Daerah dalam merestrukturisasi Birokrasi Daerah khususnya dengan diimplementasikannya Peraturan Pemerintah Nomor 84 Tahun 2000 tentang Pedoman Organisasi Perangkat Daerah dan Peraturan Pemerintah Nomor 41 Tahun 2007 Tentang Organisasi Perangkat Daerah benar - benar menjiwai semangat dari dilaksanakannya Otonomi Daerah dibawah Undang-Undang Nomor 32 Tahun 2004.

Secara lebih luas dengan adanya Restrukturisasi Birokrasi Pemerintah Daerah sebenarnya adalah dalam kerangka pengembangan kepemerintahan yang baik (Good Governance). Restrukturisasi Birokrasi Pemerintah Daerah dalam kerangka Good Governance diharapkan akan menciptakan suatu penyelenggaraan Pemerintahan Daerah yang lebih akuntabel, transparan, responsive, terbuka, efektif dan efisien, dan memberikaan perhatian khusus pada pelaku birokrasi untuk menjama realitas, karena dengan penyelenggaraan Good Governance memungkinkan semua elemen yang ada yaitu negara, sektor swasta dan masyarakat bisa terlibat secara proporsional dalam menentukan kebijakan publik yang dibuat dan akan diimplementasikan.

Suatu persoalan yang menarik untuk di kaji bahwa Kabupaten Konawe Utara berdiri sebagai daerah otonom baru semenjak 2 juli 2007 berarti sudah 3 tahun terakhir pemekaran daerah di sahkan dengan Undang-Undang Nomor 13 tentang Pemekaran wilayah, ini tentunya berkaitan dengan restrukturisasi birokrasi dan pengembangan Good Governance belum secara empirik nampak pada setiap kelembagaan Dinas, Kantor Badan pada daerah Konawe Utara karena daerah tersesbut belum definitif sebagai daerah otonom baru masih terjadi pergantian pejabat Bupati, sehingga berdasarkan pengamatan sementara penulis menganggap bahwa proses restrukturisasi birokrasi di Konawe Utara akan terlaksana dengan sesunguhnya apa bila daerah tersebut memiliki kewenangan penuh seperti Kabupaten/Kota yang lainnya.

Restrukturisasi yang di lakukan oleh Sekertariat Daerah Kabupaten Konawe Utara bahwa struktur kelembagaan secara umum pada pemerintah daerah Konawe Utara dengan 13 Dinas 8 Badan 4 kantor dan lebih khusus lagi pada bagian Sekertariat berjumlah 10 Kepala Bagian, hal ini menunjukan bahwa proses penyusunan struktur kelembagaan sudah menggunakan pola maksimal artinya dalam mewujudkan kepemerintahan yang baik (good governance) melalui kelembagaan yang telah disusun akan terlaksana dengan asas otonomi daerah sebagai roh pembangunan daerah yang efektip dan efisien.

\section{Rumusan Masalah}

Berdasarkan uraian pada latar belakang, maka yang menjadi permasalahan dalam penelitian ini dirumuskan sebagai berikut

1. Bagaimanakah Restrukturisasi Birokrasi dilakukan dalam menunjang kepemerintahan yang baik pada sekertariat Daerah Kabupaten Konawe Utara

2. Bagaimanakah Restrukturisasi Birokrasi yang dilaksanakan oleh Sekertariat Daerah Kabupaten Konawe Utara mengarah pada pengembangan good gevernance 
Vol.1 No.3. Oktober 2018. pp.1-13. Copyright@2018 PUBLICUHO Faculty of Social and Political Sciences Halu Oleo University, Kendari, Southeast Sulawesi, Indonesia. ISSN: 2460-058X | e-ISSN: 2621-1351. Open Access at: http://ojs.uho.ac.id/index.php/PUBLICUHO

Jounal publiuho is licensed under a Creative Commons Attribution 4.0 International License, which permits unrestricted use, distribution, and reproduction in any medium, provided the original work is properly cited.

\section{TINJAUAN PUSTAKA}

\section{Konsep dan Teori Restrukturisasi}

Struktur organisasi (desain organisasi) dapat didefinisikan sebagai mekanisme-mekanisme formal dengan mana organisasi dikelola. Struktur organisasi menunjukkan kerangka dan susunan perwujudan pola tetap hubunganhubungan diantara fungsi-fungsi, bagian-bagian atau posisi-posisi maupun orang-orang yang menunjukkan, tugas wewenang dan tanggung jawab yang berbeda-beda dalam suatu organisasi. (Handoko, 1995). Struktur organisasi berkaitan dengan hubungan yang relatif tetap diantara berbagai tugas yang ada dalam organisasi. Proses untuk menciptakan struktur tersebut, dan pengambilan keputusan tentang alternatif struktur disebut dengan nama desain organisasi. (Gitosudarmo, 1997). Restrukturisasi organisasi pemerintah daerah harus dilakukan mengingat pertimbangan bahwa misi pemerintahan untuk memajukan masyarakat, hanya dapat dijalankan dan dicapai jika di dalam organisasi pemerintahan itu sendiri berlangsung mekanisme sistem manejemen yang efektif, efisien dan inovatif (Rasyid,1997:121).

Restrukturisasi Birokrasi dapat diartikan sebagai sebuah proses redesain atau penataan ulang terhadap tatanan birokrasi yang telah ada. Ketika terjadi dinamika pada lingkungan baik internal maupun eksternalnya maka birokrasi juga harus mengadaptasi dinamika tersebut supaya dapat survive. Adaptasi terhadap dinamika yang terjadi menyebabkan birokrasi harus tampil sesuai dengan realitas yang ada. Restrukturisasi atau penataan kembali organisasi birokrasi pada hakekatnya adalah aktivitas untuk menyusun satuan organisasi birokrasi yang akan diserahi bidang kerja, tugas atau fungsi tertentu.

\section{Konsep dan Teori Birokrasi}

Konsep birokrasi sebagaimana yang dicetuskan oleh Max Weber menunjuk pada pengaturan pekerjaan secara hierarkis, impersonal, rasional, yurisdiktif-legalistik dan meritokrasi (Thoha, 1995).

Birokrasi dalam perspektif Weber meletakan efisiensi sebagai norma birokrasi, karena itu untuk meningkatkan efisiensi sistem pembagian kerja dalam birokrasi dikembangkan melalui spesialisasi kerja yang jelas. Pengembangan birokrasi dilakukan baik secara vertikal (hirarkis) ataupun secara horizontal dalam organisasi. Birokrasi juga harus memiliki aturan yang jelas yang mengatur hubungan kerja secara impersonal. Jabatanjabatan di birokrasi diisi oleh orang-orang yang secara teknis berkompeten atau profesional dibidangnya. Pola rekruitmen dan promosi pegawai dalam birokrasi didasarkan pada aturan formal. Para pegawai (birokrat) memandang tugas sebagai karier seumur hidup dan mendapatkan kompensasi (gaji) dari tugas yang dilaksanakan. Sumber legitimasi dari birokrasi berasal dari aturan yang berlaku (legalitas formal). Dalam konsep Weber ini birokrasi sebagai aparat administratif mempunyai peran yang menentukan tumbuh dan berkembangnya organisasi tersebut, sehingga perhatian Weberian ini lebih kepada struktur (birokrasi) yang telah diatur secara normatif dan mekanisme untuk mempertahankan struktur tersebut untuk menjamin tercapainya tujuan organisasi (Weber dalam Santoso, 1993).

\section{Konsep dan Teori Kepemerintahan yang Baik (Good Govenance)}

Kepemerintahan yang baik (Good Governance) sebagai sebuah konsep sebenarnya bukanlah sesuatu yang baru, namun pada tataran realitas khususnya di Indonesia hal ini merupakan barang baru yang langka dan mungkin hanya sebagai sebuah utopia. Konsep governance didefinisikan sebagai praktik penyelenggaraan kekuasaan dan kewenangan oleh pemerintah dalam pengelolaan urusan pemerintahan secara umum, dan pembangunan ekonomi pada khususnya.

Istilah "Governance" menunjukkan suatu proses di mana rakyat bisa mengatur ekonominya, institusi dan sumber-sumber sosial dan politiknya tidak hanya dipergunakan untuk pembangunan, tetapi juga untuk menciptakan kohesi, integrasi, dan untuk kesejahteraan rakyat. Dengan demikian, bahwa kemampuan suatu 
negara mencapai tujuan negara sangat tergantung pada kualitas tata kepemerintahan di mana pemerintah melakukan interaksi dengan sektor swasta dan masyarakat (Thoha; 2000, 12).

(Pinto dalam Nisjar, 1997). Secara sederhana Good Governance dapat diartikan sebagai kepemerintahan yang baik, sedangkan World Bank mendefinisikannya sebagai suatu penyelenggaraan manajemen pembangunan yang solid dan bertanggung jawab yang sejalan dengan prinsip demokrasi dan pasar yang efisien, penghindaran salah alokasi dana investasi, dan pencegahan korupsi baik secara politik maupun administratif, menjalankan dispilin anggaran serta penciptaan legal and political framework bagi tumbuhnya aktivitas usaha (Mardiasmo, 2002). Good Governance dapat diartikan pula sebagai hubungan yang sinergis dan konstruktif di antara negara, sektor swasta dan masyarakat (society) (UNDP dalam AKIP LAN, 2001). Dalam Good Governance terdapat empat unsur, yaitu akuntabilitas (accountability), transparansi (transparency), keterbukaan (openness), dan aturan hukum (rule of law) (Bhatta dalam Widodo, 2001).

\section{Kerangka Pemikiran}

Restrukturisasi Birokrasi dapat diartikan sebagai sebuah proses redesain atau penataan ulang terhadap tatanan birokrasi yang telah ada. Ketika terjadi dinamika pada lingkungan baik internal maupun eksternalnya maka birokrasi juga harus mengadaptasi dinamika tersebut supaya dapat survive. Adaptasi terhadap dinamika yang terjadi menyebabkan birokrasi harus tampil sesuai dengan realitas yang ada. Restrukturisasi atau penataan kembali organisasi birokrasi pada hakekatnya adalah aktivitas untuk menyusun satuan organisasi birokrasi yang akan diserahi bidang kerja, tugas atau fungsi tertentu.

Penyusunan struktur organisasi menurut Siagian (2000) harus memperhatikan 4 faktor pendekatan situasional, yaitu : ( a ) Struktur organisasi harus sesuai dengan tugas untuk menghilangkan kesan bahwa organisasi terlalu besar dan rumit. Struktur organisasi dikaitkan dengan misi yang harus diemban, strategi yang ditetapkan, uraian tugas institusional dan personal, tersedianya tenaga kerja yang memiliki pengetahuan dan keterampilan yang spesialistik, dukungan anggaran, serta tersedianya sarana dan prasarana kerja; (b) Pengurangan jarak kekuasaan. Mengurangi jarak kekuasaan berarti penciptaan organisasi yang datar, peningkatan intensitas dan frekuensi komunikasi langsung antara atasan dan bawahan, pemberdayaan para bawahan, terutama dalam bentuk kesempatan turut terlibat aktif dalam proses pengambilan keputusan, penilaian yang simpatik, dan sistem penilaian kinerja bawahan yang objektif; (c) Kemungkinan penggunaan tipe-tipe organisasi lain. Seperti diketahui, berbagai tipe organisasi yang dapat digunakan ialah organisasi fungsional, organisasi matriks, dan kepanitiaan atau adhocracy. Dengan menggunakan salah satu tipe organisasi tersebut, kinerjanya akan memuaskan, tingkat efisiensi, efektivitas, dan produktivitasnya tinggi, mampu memberikan pelayanan dengan cepat, dan kepuasan kliennya terjamin; (d) Salah satu prinsip organisasi yang harus dipahami adalah keseimbangan antara wewenang dan tanggung jawab. Hal ini berarti struktur apapun yang digunakan harus menjalin keseimbangan antara wewenang dan tanggung jawab yang mencerminkan kebijakan pimpinan dalam menerapkan pola desentralisasi untuk pengambilan keputusan.

Mendasari pada uraian terdahulu, maka dapat dikemukakan bahwa pengertian Birokrasi Pemerintah Daerah dalam penelitian ini adalah Perangkat Daerah. Perangkat Daerah adalah organisasi/lembaga pada Pemerintah Daerah yang bertanggung jawab kepada Kepala Daerah dan membantu Kepala Daerah dalam penyelenggaraan pemerintahan. Sesuai dengan lokus dari penelitian ini maka pengertian Birokrasi Pemerintah Daerah adalah menunjuk kepada Perangkat Daerah yang ada di Kabupaten Konawe Utara. 
Vol.1 No.3. Oktober 2018. pp.1-13. Copyright@2018 PUBLICUHO Faculty of Social and Political Sciences Halu Oleo University, Kendari, Southeast Sulawesi, Indonesia. ISSN: 2460-058X | e-ISSN: 2621-1351. Open Access at: http://ojs.uho.ac.id/index.php/PUBLICUHO

Jounal publiuho is licensed under a Creative Commons Attribution 4.0 International License, which permits unrestricted use, distribution, and reproduction in any medium, provided the original work is properly cited.

\section{METODE PENELITIAN}

\section{Desain Penelitian}

Desain Penelitian yang akan digunakan dalam penelitian ini adalah deskriptif kualitatif, yaitu bahwa prosedur pemecahan masalah yang diselidiki dengan menggambarkan atau melukiskan keadaan subjek atau objek penelitian (seseorang, lembaga, masyarakat dan lainnya) pada saat sekarang berdasarkan fakta-fakta yang tampak atau sebagaimana adanya. Dalam melengkapi data yang diperlukan juga digunakan tehnik observasi, wawancara dan studi dokumentasi terhadap pimpinan bagian untuk memperkuat dan mendalami faktor faktor yang diteliti.

\section{Populasi dan Sampel}

Penelitian ini dilakukan di Sekertariat Kabupaten Konawe Utara, populasi penelitian ini adalah seluruh Kepala Bagian Sekertariat Daerah Kabupaten Konawe Utara yaitu sebanyak 10 orang Kabag dan satu orang Sekertaris Daerah (Sekda). Penelitian yang dilakukan bersifat sensus karena seluruh populasi dijadikan responden penelitian.

\section{Teknik pengumpulan data}

1. Wawancara, penulis mengadakan dialog langsung dengan narasumber yang dinilai dapat memberikan informasi yang akurat dan tepat mengenai hal yang menyangkut proses restrukturisasi birokrasi yang dilaksanakan oleh Pemerintah Daerah Kabupaten Konawe Utara mengarah pada penegembangan Good Governance, ditinjau dari aspek kompetensi administrasi, transparansi dan efisiensi.

2. Obeservasi, penulis melakukan pengamatan langsung ke objek penelitian untuk melihat atau menyaksikan lansung apa yang terjadi penomena dilapangan. Dengan pengamatan ini diharapkan dapat mencatat peristiwa dalam situasi yang berkaitan dengan pengetahuan proposisional maupun pengetahuan yang langsung diperoleh dari data; memahami situasi-situasi sulit yang berkembang dan sebagai re-check data yang ada sebagaimana dikemukakan oleh Guba dan Lincoln (Moleong, 2001: 125126).

3. Studi dokumentasi, penulis mengkaji naskah-naskah, buku-buku, literatur dan peraturan-peraturan yang berkenaan dengan Restrukturisasi Birokrasi dan Pengembangan Good Governance pada Pemerintah Daerah Kabupaten Konawe Utara.

\section{PEMBAHASAN}

Hasil penelitian terhadap indikator jenjang pendidikan di peroleh hasil yang cukup tinggi. Hal ini berarti bahwa sumber daya manusia pada Sekertariat Daerah dilihat dari dimensi jenjang pendidikan telah mampu menunjang kinerja Sekertariat Daerah.

Penjelasan Informan menunujukan bahwa, dilihat dari dimensi jenjang pendidikan maka dapat dikatakan sumber daya manusia pada lingkup Sekertariat Daerah Kabupaten Konawe Utara sudah baik atau meningkat, sehingga dimungkinkan akan mampu melaksanakan tugas pokok dan fungsinya sebagai birokrasi yang dapat memberikan pelayanan kepada publik. Meskipun terlihat ada beberapa diantaranya masih belum sarjana, tetapi mereka adalah stap sekertariat tentunya akan lebih banyak membantu kepada tenaga inti sehingga secara keseluruhan akan tercipta peranan yang saling berkaitan sehingga tugas-tugas administrasi terlaksana dengan tepat guna. Apalagi dengan adanya beberapa stap yang melanjutkan pendidikan ke starata satu (Sl) dan strata 
dua (S2) maka hal ini tentunya semakin menunjang pelaksanaan tugas-tugas administrasi pada Sekertariat Daerah tersebut.

Hal ini sesuai pula dengan pandangan Moeljarto (1996:89), yang menyatakan bahwa seorang aparat dalam suatu organisasi harus mempunyai kualitas sumber daya manusia yang memadai sehingga dia mampu memahami tugas pokok dan fungsinya dalam organisasi dan mampu melihat berbagai peluang,tantangan,hambatan dan kesempatan organisasi yang terkait dengan tugasnya sehari-hari. Hal ini sesuai dengan pendapat T.Hani Handoko (1987: 4), yang mengemukakan bahwa: "Manajemen personalia diperlukan untuk meningkatkan efektifitas Sumber Daya Manusia dalam organisasi, tujuannya adalah untuk memberikan kepada satuan organisasi kerja yang efektif".

Dengan merujuk pada pembahasan diatas, maka Kabupaten Konawe Utara sebagai Kabupaten baru, untuk dapat menjalankan organisasi pemerintahannya dengan baik haruslah benar-benar menyesuaikan dengan kondisi lingkungan yang ada serta berupaya dengan semaksimal mungkin untuk dapat memanfaatkan potensi ataupun memberdayakan sektor-sektor potensial yang ada di Kabupaten Konawe Utara, sehinggga dengan begitu organisasi tersebut dalam hal ini Kabupaten Konawe Utara dapat mancapai suatu organisasi pemerintahan yang efektif dan efesien didalam menyelenggarakan pemerintahannya meningkatkan kapasiatas sumber daya manusia.

Hasil penelitian terhadap dimensi jenjang kepangkatan atau golongan pada lingkup Sekertariat Daerah sudah cukup memadai. Diperoleh tanggapan Imporman menyatakan bahwa jenjang kepangkatan mempengaruhi tugas-tugas administrasi, asumsinya bahwa semakin tinggi golongan seseoarang semakin tinggi pula penguasaan pekerjaan yang dihadapinya. Hal ini di perkuat oleh Informan kunci memberikan penjelasan bahwa : jika dilihat dari jenjang kepangkatan atau golongan pada aparat Sekertariat Daerah Kabupaten Konawe Utara dapat dikatakan bahwa sudah memiliki standar yang baik karena di buktikan dengan ada 45 orang yang berpangkat golongan ruang IV, ini artinya bahwa jikalau berkenaan dengan tugas yang dihadapi dilingkup Sekertariat Daerah maka dengan sendiri akan mudah karena di tunjang dengan kapasitas golongan yang memadai.

Hal yang serupa dikemukakan pula oleh Ginanjar Kartasasmita (1996 : 113 ) bahwa pengembangan manusia sebagai sumber daya pembangunan menekankan manusia sebagai pelaku pembangunan yang memiliki etos kerja produktif, keterampilan,kreativ, disiplin, profesional, serta mempunyai kemampuan memanfaatkan, mengembangkan dan menguasai ilmu pengetahuan dan teknologi serta kemampuan manajemen. Oleh karena itu kemampuan sumber daya manusia sangat ditentukan jenjang kepangkatan dalam kepegawaian yang dimilkinya. Sehingga jenjang kepangkatan atau golongan mereka. Maka tugas-tugas organisasi dalam hal ini pada lingkup Sekertariat Daerah Kabupaten Konawe Utara dapat dilaksanakan secara efektif dan efisien.

Dengan demikian bahwa keseuaian struktur organisasi yang tersedia pada lingkup sekertariat daerah harus menyatu dengan jenjang kepangkatan atau perpindahan golongan ruang yang tersedia sebab organisasi dalam menjalankan fungsinya berdasarkan struktur yang ada dan sumber daya yang tersedia harus sesuai aturan yang berlaku dalam organisasi birokrasi Sekertariat Daerah.

Hasil penelitian terhadap dimensi keadaan umur pada lingkup Sekertariat Daerah masih produktif. Hal ini menujukan bahwa dilihat dari keadaan umur pegawai Sekertariat Daerah Kabupaten Konawe Utara relatif etos kerjanya masih tinggi karena rata-rata usia produktif sehinga kepuasan kerja yang akan dicapai dalam kesatuan organisasi terwujud secara efektif. Hal ini sama pula apa dinyatakan oleh salah seorang informan bahwa kondisi umur mempengaruhi keadaan pekerjaan karena semakin tinggi usia seseorang maka semakin rendah pula etos kerja sehingga kepuasan kerja yang di inginkin dalam lingkup organmisasi tidak memadai.

Oleh karena itu, Jewell dan Siegall (1998 ) Umur ada kecenderungan karyawan yang lebih tua lebih merasa puas dari karyawan yang berumur relatif lebih muda. Hal ini diasumsikan bahwa karyawan yang lebih tua telah 
Vol.1 No.3. Oktober 2018. pp.1-13. Copyright@2018 PUBLICUHO Faculty of Social and Political Sciences Halu Oleo University, Kendari, Southeast Sulawesi, Indonesia. ISSN: 2460-058X | e-ISSN: 2621-1351. Open Access at: http://ojs.uho.ac.id/index.php/PUBLICUHO

JC Jounal publiuho is licensed under a Creative Commons Attribution 4.0 International License, which permits
unrestricted use, distribution, and reproduction in any medium, provided the original work is properly cited.

berpengalaman sehingga ia mampu menyesuaikan diri dengan lingkungan pekerjaan, sedangkan karyawan usia muda biasanya mempunyai harapan yang ideal tentang dunia kerjanya, sehingga apabila harapannya dengan realita kerja terdapat kesenjangan, atau ketidakseimbangan dapat meyebabkan mereka menjadi tidak puas. Hal ini tentunya kemampuan sumber daya manusia sangat ditentukan oleh jenjang pendidikan, jenjang kepangkatan atau golongan ruang dan keadaan umur yang dimilikinya masing-masing pegawai atau karyawan, sehingga dengan demikian tugas pokok dan fungsinya menjadi landasan gerak dalam melakukan kegiatan dan tugas seperti halnya pada lingkup Sekertariat Daerah dimana instansi tersebut kompleksitas permasalahan begitu banyak, sehingga dibutuhkan sember daya manusia yang memadai dalam melakukan tugas organisasi secara efektif.

Dengan demikian restrukturisasi birokrasi pada lingkup Sekertariat Daerah menggunakan kemampuan sumber daya manusia melalui jalur pendidikan formal, jenjang kepangkatan dan kondisi umur dan setelah itu dengan analisis kesesuaian struktur dan fungsinya memberikan gambaran bahwa analisis yang dipergunakan akan menunjang proses pelaksaan kepemerintahan yang baik

Analisis pengurangan jarak kekuasaan dari hasil penelitian terhadap dimensi penguarangan jarak kekuasaan di peroleh tanggapan dari Informan bahwa mengurangi jarak kekuasaan berarti menciptakan restrukturisasi kondisi organisasi yang harmonis dan itu memberikan kesan yang positif antara atasan dengan bawahan karena ada perubahan metode dalam mengelola organisasi. Pengurangan jarak kekuasaan bukan berarti meninggalkan kaidah-kaidah normatif yang menjadi identitas dalam organisasi, mengurangi jarak kekuasaan dapat menciptakan organisasi yang datar pekah terhadap kondisi pegawai, peningkatan intensitas dan frekuensi kordinasi langsung antara atasan dan bawahan, pemberdayaan para bawahan, terutama dalam bentuk kesempatan turut terlibat aktif dalam proses pengambilan keputusan, penilaian kerja bawahan yang obyektif.

Tentu hal ini sejalan dengan pandangan Scott (Muhyadi, 1989) Pengurangan situasi jarak kekuasaan didalamnya terdapat upaya - upaya untuk memprediksi dan menjelaskan dengan tingkah laku, perilaku, dan yang kedua merupakan situasi yang harus dilakukan dalam menghubungkan jaringan sosial internal organisasi terdapat komunikasi sebagai system saling mempengaruhi antara orang dalam kelompok yang bekerja sama untuk mencapai tujuan tertentu.

Dengan demikian tepat kiranya bila kita menyebutkan bahwa tujuan dari restrukturisasi dengan dimensi pengurangan jarak kekuasaan merupakan pengembangan organisasi masa kini, sebab memungkinkan akan memberikan nilai tambah terhadap efektivitas organisasi pada lingkup Sekertariat Daerah Kabupaten Konawe Utara.

Berdasarkan pada hasil penelitian, dapat dijelaskan bahwa model pengurangan jarak kekuasaan yang dilakukan oleh birokrasi sekertariat daerah Kabupaten Konawe Utara belum dilakukan oleh aparat secara masiv karena masih terbatasnya sumber daya manusia sarana dan prasarana yang dimiliki

Analisis Kemungkinan Penggunaan Tipe-Tipe Organisasi hasil penelitian terhadap dimensi tersebut berdasarkan tanggapan Informan bahwa Penggunaan tipe organisasi pemerintahan menyesuaikan dengan dinamika kebutuhan daerah dan memperhatikan potensi-potensi yang berkembang, terbukti selama ini konsep atau metode yang dijalankan masih mengandalkan arus bawah artinya masyarakat menjadi obyek dan sekaligus juga subyek dalam setiap kebijakan.

Penjelasan Informan memberikan gambaran bahwa penggunaan tipe organisasi merupakan simbol atau pemberi keterangan yang akan dijalankan dalam roda organisasi birokrasi, dari pandangan tersebut diatas mempertegas adanya standarisasi yang di inginkan untuk bagaimana seluruh komponen organisasi Sekertariat Daerah Kabupaten Konawe Utara dapat menjalankan tugas pokok dan fungsi sesuai dengan asas otonomi daerah, sebagai konsekuensi dan kehendak daerah otonom sebagaimana yang tertuang dalam pemerintah daerah. Demikian pula komponen restrukturisasi digolongkan melalui penggunaan tipe organisasi yang di jalankan oleh seluruh aparat birokrasi yang bernaung dalam lingkup Sekertariat Daerah. 
Hal ini pula serupa pandangan Luther Gulick ( syahrir 2003 : 56 ) Organisasi adalah sebagai suatu alat saling hubungan satuan-satuan kerja yang memberikan mereka kepada orang-orang yang ditempatkan dalam struktur kewenangan dengan demikian pekerjaan dapat dikoordinasikan oleh perintah para atasan kepada para bawahan yang menjangkau dari puncak sampai ke dasar dari seluruh badan organiasasi.

Lebih lanjut pandangan yang dikemukakam oleh (Siagian : 2000) tipe Organisasi divisi. Dalam pandangan teori perilaku organisasi, organisasi divisi memberikan alat bagi untuk memberi penekanan pada pengendalian pada manajer dengan memilah-milahkan aspek-aspek yang dapat dikendalikan. Bentuk organisasi divisi berorientasi kepada sistem terbuka yang menekankan pada tanggungjawab manajer divisi untuk menyadari pengaruhpengaruh luar setempat yang menimpa kegiatan-kegiatan organisasi. \

Berdasarkan hasil diatas maka dapat di interprestasikan bahwa penggunaan tipe organisasi sekertariat daerah Kabupaten Konawe Utara masih berdasarkan Peraturan Daerah Kabupaten Konawe Utara Nomor 2 Tahun 2008 tentang pembentukan organisasi Sekertariat Daerah, telah sesuai dengan pengendalian tugas dalam melaksanakan administrasi pemerintahan secara umum dilingkup Sekertariat Daerah yang terdiri dari 10 bagian 3 sub bagian sehingga dengan demikian tipe tersebut dapat mengakomodir kebutuhan organisasi baik secara internal maupun eksternal birokrasi Sekerariat Daerah.

Analisis keseimbangan wewenang dan tanggungjawab hasil penelitian terhadap dimensi tersebut berdasarkan tanggapan Informan bahwa didalam tubuh organisasi Sekertariat Daerah Kab. Konut yang terdiri dari Kepala Bagian dan diantara Kabag membawahi tiga Sub Bagian, maka dengan telah dibagi habis tugas sesuai bidang masing-masing mengacu pada PP Nomor 41 Tahun 2007 tentang Organisasi Perangkat Daerah, baik pelimpahan tugas secara personal maupun tugas secara kelembagaan dan masing-masing unit sudah mengetahui tugas pokok, jadi wewenang diberikan kepada Kabag sudah diatur dalam peraturan pemerintah

Kemudian tanggapan Informan selanjutnya bahwa kemampuan pada penanggungjawab dalam melakukan kordinasi dalam organisasi. komunikasi dan kordinasi merupakan usaha yang dilakukan pada pimpinan guna menyelaraskan antara unit-unit kerja dan tugas antara pejabat organisasi, dengan demikian dapat tercipta sinergitas wewenang dan tanggungjawab itu merupakan harapan yang harus di optimalkan fungsi dari masingmasing unit kerja. Kordinasi dan konsultasi juga di perlukan dalam rangka terwujudnya kesatuan visi, presepsi dan interprestasi dari masing-masing kesatuan unit kerja. Keadaan ini diharapkan melahirkan kesatuan usaha dan tindakan yang pada gilirannya akan menjamin keseimbangan wewenang tugas dan tanggung jawab dalam organisasi.

Oleh karena itu pandangan yang di kemukakan oleh David Osborne dan Ted Gaebler $(1992,13-22)$ bahwa Ada keharusan untuk melakukan semua kewajiban/tugas-tugas yang dibebankan kepadanya sebagai akibat dari wewenang yang diterima atau dimilikinya. Tanggungjawab tidak dapat dilimpahkan kepada orang lain. Wewenang diterima, maka tanggungjawab harus juga diterima dengan sebaik-baiknya. Inilah sebabnya top manager yang menjadi penangung jawab terakhir mengenai maju/mundurnya suatu perusahaan.

Dengan demikian dapat diinterprestasikan bahwa dalam penerapan kesesuain wewenang dan tanggungjawab merupakan pelaksanaan restrukturisasi. Jadi birokrasi Sekertariat Daerah sudah menjalankan konsep restrukturisasi birokrasi. Mencermati hasil penelitian diatas maka dapat dijelaskan bahwa restrukturisasi birokrasi Sekertariat Daerah dengan melalui wewenang dan tanggung jawab yang dibebankan oleh masing masing unit satuan kerja menunjukan adanya keseimbangan tugas pokok dan fungsi dalam melaksanakan tugas yang meliputi pembinaan pengawasan dan pengembangan organisasi sesuai prosedur serta dikordinasikan secara hirearkis.

Mencermati hasil diatas maka dapat disimpulkan bahwa restrukturisasi birokrasi Sekertariat Daerah dengan melalui wewenang dan tanggung jawab yang dibebankan oleh masing - masing unit satuan kerja menunjukan 
Vol.1 No.3. Oktober 2018. pp.1-13. Copyright@2018 PUBLICUHO Faculty of Social and Political Sciences Halu Oleo University, Kendari, Southeast Sulawesi, Indonesia. ISSN: 2460-058X | e-ISSN: 2621-1351. Open Access at: http://ojs.uho.ac.id/index.php/PUBLICUHO

Jounal publiuho is licensed under a Creative Commons Attribution 4.0 International License, which permits unrestricted use, distribution, and reproduction in any medium, provided the original work is properly cited.

adanya keseimbangan tugas pokok dan fungsi dalam melaksanakan tugas yang meliputi pembinaan pengawasan dan pengembangan organisasi sesuai prosedur serta dikordinasikan secara hirearkis.

Kepemerintahan yang baik (Good Governance) terdiri dari tiga konsep yaitu: Kompetensi, Efektifivitas dan Akuntabilitas. Dalam konsep kompetensi dibagi dua yaitu di bagi yaitu: kompetensi lembaga dan kompetensi personil.

Dari hasil penelitian kompetensi lembaga bahwa berdasarkan Peraturan Daerah Kabupaten Konawe Utara Nomor 2 Tahun 2008 Tentang Pembentukan, Susunan Organisasi dan Tata Kerja Perangkat Daerah Kabupaten Konawe Utara yang ditetapkan pada tanggal 11 Juni 2008 telah menghasilkan 10 Bagian pada Sekertariat Daerah Kabupaten Konawe Utara. Mengenai kondisi kelembagaan khususnya dilihat dari visi dan misi, didapat dari wawancara dengan salah seorang Pejabat yang berkompeten dikatakan bahwa seluruh organisasi yang ada di jajaran Sekertariat Daerah Kabupaten Konawe Utara tidak satupun yang memiliki visi maupun misi organisasi, sebab saya sekarang ini sedang melakukan inventarisir terhadap semua permasalahan yang dihadapi oleh semua lembaga yang ada.

Pandangan diatas sejalan dengan salah seorang Informan bahwa belum membuat visi dan misi organisasi dikarenakan visi dan misi Kabupaten sendiri belum ada dan kami masih dalam menunggu Bupati yang definitif . Mungkin nanti kalau sudah definitif visi dan misi kabupaten maka kami juga akan membuat visi dan misi organisasi dengan berpedoman pada visi dan misi kabupaten tersebut namun demikian meskipun kami tidak memiliki visi dan misi organisasi kami masih bisa melaksanakan tugas dan tanggungjawab dengan baik dengan berdasarkan tugas pokok dan fungsi dari organisasi yang telah kami miliki. Hal ini sesuai pandangan Purwanto (2006:8) mengemukakan bahwa kompetensi adalah suatu persyaratan kemampuan dalam melaksanakan jabatan. Biasanya kemampuan ini dikaitkan dengan keahlian, keterampilan dan profeionalisme, kompetensi jabatan fungsional/struktural, demikian juga dengan kompetensi jabatan negara /politik, perbedaan ini menunjukan karena tugas pokok fungsinya, wewenang dan tanggungjawab.

Dalam rangka peningkatan kompetensi lembaga dengan serangkaian pandangan Informan diatas tentunya lembaga organisasi Sekertariat Daerah yang melakukan pembenahan struktur, sehingga tugas pokok dan fungsi masing-masing unit kerja berjalan sesuai karakteristik birokrasi yang baik dalam rangka mewujudkan good governance.

Dari hasil penelitian mengenai kompetensi personil diperoleh informasi Kasubag Analisis Jabatan dan Ketatalaksanaan. Bahwa untuk mengisi jabatan-jabatan yang ada di organisasi Pemerintah Daerah sebagai bentuk promosi, maka pertimbangan senioritas khususnya pangkat dan Diklat penjenjangan masih sangat penting, karena dalam jabatan struktural tidak mungkin seorang yang eselonnya diatas, pangkat dan Diklat penjenjangannya lebih rendah dari pada yang dibawahinya, meskipun bawahan tersebut memiliki predikat S3 sekalipun.

Pandangan yang dikemukakan oleh Hooghiemstra (dalam Atmosoeprapto, 2000:59) didefinisikan sebagai suatu sifat dasar seseorang yang dengan sendirinya berkaitan dengan pelaksanaan suatu pekerjaan secara ketidaksamaan dalam kompetensi-kompetensi. Inilah yang membedakan seseorang perilaku unggul dari perilaku yang berprestasi rata-rata. Untuk mencapai kinerja sekedar cukup atau rata-rata diperlukan kompetensi batas atau kompetensi esensial. Kompetensi batas dan kompetensi istimewa tertentu merupakan pola atau pedoman dalam pemilihan karyawan, perencanaan pengalihan tugas dan penilaian kinerja.

Berdasarkan pandangan diatas maka kompetensi personil yang dimiliki oleh aparatur Sekertariat Daerah dalam melaksanakan suatu pekerjaan belum secara efektif dan efisien. Dengan demikian kompetensi lembaga dan Kompetensi personil birokrasi Sekertariat Daerah Kabupaten Konawe Utara secara absah belum terampil dan kapasitas sumber daya manusia yang dimiliki konkrit dinyatakan belum mempunyai kesiapan untuk menciptakan kepemerintahan yang baik. 
Efektivitas organisasi dapat dilihat sejauhmana organisasi tersebut dapat mencapai tujuan yang sudah ditetapkan yang menunjukkan pada tingkat pelaksanakan kegiatan atau fungsi-fungsi sehingga tujuan yang telah ditetapkan dapat tercapai dengan menggunakan alat-alat dan sumber-sumber yang ada secara optimal. Berarti bicara mengenai efektivitas organisasi ada dua aspek didalamnya yaitu: 1) Tujuan organisasi dan 2) Pelaksanaan fungsi atau cara untuk mencapai tujuan tersebut.

Hasil wawancara menunjukan dilingkup Sekertariat Daerah, tentunya mengenai efektifitas organisasi yang telah kami laksanakan tidak jauh beda dengan kabupaten lain, artinya target realisasi pekerjaan tidak meleset dari apa yang telah di sepakati pada sidang pembahasan antara pihak eksekutif dan legislatif, namun hal yang menjadi catatan kaki bagi kami, bahwa di dalam melaksanakan tugas-tugas masih kadang terhambat karena mobilitas sarana perkantoran masih mengalami keterbatasan, sehingga kadang pekerjaan administrasi di bawah di kendari untuk menyelesaikannya/memburu target yang telah di tentukan, bukan saja di lingkup sekertariat, tetapi pada SKPD lain pun terjadi seperti itu.

Untuk mencapai efektivitas organisasi dalam membangun keberhasilan di era otonomi daerah tergantung pada efektivitas organisasi Sekertariat daerah sebagai institusi pemerintah daerah yang hadir untuk melayani masyarakat dan menempatkan masyarakat sebagai pemegang saham, sehingga perlu perhatian serius dalam memberikan pelayanan. Kesemuanya ini memerlukan aparat pelaksana yang mempunyai hubungan kerjasama untuk mencapai tujuan organisasi yang telah ditetapkan berdasarkan visi, misi serta rencana strategik organisasi Sekertariat Daerah Kabupaten Konawe Utara.

Hal ini sesuai hasil wawancara dengan Kabag. Humas kutipan sebagai berikut: Tentunya didalam melakukan target realisasi tugas kami selalu berupaya agar diefektifkan seluruh sumber-sumber daya yang di pergunakan dalam rangka memaksimalkan potensi daerah yang dimilki sehingga tidak terkesan kaya struktur miskin fungsi (hasil wawancara Maret 2011). Oleh karena itu pandangan yang di kemukakan Hall (1974: 96) mengartikan bahwa dengan tingkat sejauhmana suatu organisasi merealisasikan tujuannya. Semua konsep tersebut hanya menunjukkan pada pencapaian tujuan organisasi, sedang bagaimana cara mencapainya tidak dibahas. Yang membahas bagaimana mencapai tingkat efektivitas adalah Argris (dalam Siliss, 1968: 312) yang mengatakan: Efektivitas organisasi adalah keseimbangan atau pendekatan secara optimal pada pencapaian tujuan, kemampuan dan pemanfaatan tenaga manusia.

Sedangkan menurut Jones (1994) terdiri dari tiga tahap, yakni input, conversion, dan output atau masukan, perubahan dan hasil. Input meliputi semua sumber daya yang dimiliki, informasi dan pengetahuan, bahanbahan mentah serta modal. Dalam tahap input, tingkat efisiensi sumber daya yang dimiliki sangat menentukan kemampuan yang dimiliki. Tahap conversion ditentukan oleh kemampuan organisasi untuk memanfaatkan sumber daya yang dimiliki, manajemen dan penggunaan teknologi agar dapat menghasilkan nilai. Dalam tahap ini, tingkat keahlian SDM dan daya tanggap organisasi terhadap perubahan lingkungan sangat menentukan tingkat produktifitasnya. Sedangkan dalam tahap output, pelayanan yang diberikan merupakan hasil dari penggunaan teknologi dan keahlian SDM. Organisasi yang dapat memanfaatkan sumber daya yang dimilikinya secara efisien dapat meningkatkan kemampuannya untuk meningkatkan pelayanan dengan memuaskan kebutuhan pelanggan.

Dengan demikian organisasi Sekertariat Daerah dalam pengunaan sumber daya telah secara efektif dilakukan karena target realisasi pekerjaan selesai sesuai jadwal yang telah ditentukan sebelumnya, maka dari dimensi efektivitas dapat menunjang pelaksanaan kepemerintahan yang baik.

Akuntabilitas organisasi dapat diukur dengan melihat sejauhmana aktivitas organisasi pemerintahan yang baik akuntabilitas pula dapat diukur melalui pelayanan yang diberikan dengan memberikan kepuasan yang dilayani akuntabilitas tadi, secara global dapat diartikan sebagai kata Stephen R. Covey, penulis buku The Seven Habits of Highly Effective People" untuk mengakui atau mempertanggungjawabkan suatu tindakan, aksi, keputusan, dan kebijakan yang menyangkut administrasi atau pemerintahan yang mana terdapat peran posisi 
Vol.1 No.3. Oktober 2018. pp.1-13. Copyright@2018 PUBLICUHO Faculty of Social and Political Sciences Halu Oleo University, Kendari, Southeast Sulawesi, Indonesia. ISSN: 2460-058X | e-ISSN: 2621-1351. Open Access at: http://ojs.uho.ac.id/index.php/PUBLICUHO

Jounal publiuho is licensed under a Creative Commons Attribution 4.0 International License, which permits unrestricted use, distribution, and reproduction in any medium, provided the original work is properly cited.

atau jabatan yang bertanggung jawab terhadap segala konsekuensi dan sehingga berkewajiban untuk menjelaskan atau menerima tanggung jawab dimata hukum dan masyarakat", atau singkatnya pengetahuan bahwa dalam setiap aksi selalu ada yang bertanggung jawab atau akuntabel terhadap aksi tersebut. Sehigga dengan demikian sebagai posisi yang memberikan pelayanan dapat mempertanggungjawabkan tugas yang diberikan oleh atasannya jadi akuntabel terhadap pelaksanaan pemerintahan yang baik (good governance).

Sesuai hasil wawancara melalui Sekertaris Daerah (Sekda) mengatakan bahwa : Dalam memberikan pelayanan telah dilakukan dengan tetap mengacu pada asas-asas pelayanan sebagai acuan bagi aparat sehingga tidak menimbulkan adanya sikap apriori terhadap apa yang diberikan pada customer dalam kaitanya dengan permohonan mereka sebagai pihak yang meminta layanan, dan pelayanan yang diberikan selama ini tidak semaksimal mungkin apa yang menjadi harapan karena aparat birokrasi Sekertariat Daerah tidak berada di tempat akibat dari pasilitas sarana dan prasarana yang tersedia kurang memadai , dan selaku Sekda Konawe Utara terus berupaya melakukan pembenahan -pembenahan pada aparat birokrasi lingkup sekertariat Daerah.

Samuel Paul (Modul AKIP, 2000) yakni menyangkut pertanggungjawaban pemerintah kepada pimpinan politik yang telah memlih mereka. Akuntabiltas ini dilakukan secara berjenjang dari pimpinan tingkat bawah sampai pimpinan tingkat atas. Lebih lanjut pandangan Mario D. Yango (Modul AKIP, 2000:26-27) Regularity accountability, yakni memfokuskan pada transaksi-transaksi fiskal untuk mendapatkan informasi mengenai kepatuhan pada peraturan. Managerial Accountability, yakni menitikberatkan pada efsiensi dan kehematan penggunaan sumber daya manusia dan sumber daya lainnya.

Sehingga perwujudan atau pelaksanaan pelayanan pada administrasi perkantoran khususnya dilingkup Sekertariat Daerah Kabupaten Konawe Utara merupakan sarana proses untuk pelaksaan pemerintahan yang baik, dengan demikian pertanggungjawaban setiap tindakan administratif dari aparat pemerintah di lingkup sekertariat memberikan pelayanan secara akuntabel dalam rangka menciptakan kompetensi kelembagaan,kompetensi personil secara efektif untuk menunjang kepemerintahan yang baik (Good Governance) sebagai cita-cita organisasi secara keseluruhan.

\section{KESIMPULAN}

Berdasarkan uraian dan pembahasan di atas maka penulis menarik simpulan penelitian bahwa:

1. Pelaksanaan restrukturisasi yang dilakukan pada lingkup Sekertariat Daerah telah sesuai dengan prosedur atau mekanisme peraturan dan perundang -undangan yang berlaku.

2. Restrukturisasi dari segi kesesuaian struktur. pengurangan jarak kekuasaan, penggunaan tipe organisasi dan keseimbangan wewenang dan tanggungjawab yang dilakukan oleh birokrasi Sekertariat Daerah Kabupaten Konawe Utara belum dilakukan oleh aparat secara masiv karena masih terbatasnya sumber daya manusia sarana dan prasarana yang dimiliki.

3. Pelaksanaan kepemerintahan yang baik dilingkup Sekertariat Daerah Kabupaten Konawe Utara berdasarkan temuan lapangan meliputi : (a) menggunakan indikator kompetensi lembaga dan kompetensi personil, kompetensi lembaga dan kompetensi personil pada lingkup Sekertariat Daerah menunujukan adanya pengisian formasi jabatan struktural yang sesuai dengan kompetensi yang dimiliki oleh masingmasing lembaga dan individu. (b) efektivitas penggunaan sumber daya aparat, dana organisasi sarana dan prasarana sesuai dengan target dan realisasi program yang dilakukan pada dilingkup Sekertariat Daerah Kabupaten Konawe Utara. (c) indikator akuntabilitas dilingkup Sekertariat Daerah, kebijakan yang menyangkut administrasi atau urusan pelayanan publik dapat diwujudkan sesuai tugas pokok dan fungsi pada unit satuan kerja perangkat daerah. 


\section{SARAN}

Sebaiknya kepada seluruh aparat Sekertariat Daerah Kabupaten Konawe Utara segera melakukan desain kelembagaan atau pembenahan struktur yang ada, karena struktur yang ada berdasarkan temuan dilapangan memungkinkan terjadinya kaya struktur miskin fungsi /terlalu gemuk atau juga interprestasi terhadap tupoksi yang ada tidak mampu diterjemahkan dalam bentuk program kerja. Sebagai bahan masukan penulis perlu melakukan pengkajian ulang terhadap kelembagaan yang ada pada lingkup Sekertariat Daerah, karena berdasarkan analisis dan pertimbangan konfrehensip bahwa pelaksanaan kepemerintahan yang baik (Good Governance) belum secara keseluruhan dilaksanakan sehingga restrukturisasi birokrasi pada sekertariat daerah akan mengalami perubahan bentuk artinya dapat menyesuaikan dengan kebutuhan yang dinginkan dan ke depannya kami berharap tidak terulang kembali.

\section{DAFTAR PUSTAKA}

Gitosudarmo, Indriyo dan I Nyoman Sudita, 1997, Perilaku Organisasi, BPFE, Yogyakarta.

Handoko, T. Hani, 1995, Manajemen, BPFE, Yogyakarta.

Jones, Gareth R. 1994. Organizational Theory, Text and Cases. USA. Wesley Publishing Company, Reading Massachusets.

Kartasasmita, Ginanjar,1996. Pembanguan Untuk Rakyat Memadukan pertumbuhan dan Pemertaan, CIDES, Jakarta

LAN dan BPKP. 2000. Akuntabilitas dan Good Governance. (AKIP). Jakarta : LAN RI.

Mardiasmo, 2002, Otonomi dan Manajemen Keuangan Daerah, Andi, Yogyakarta.

Moleong, Lexy J., 2000, Metodologi Penelitian Kualitatif, Remaja Rosda Karya, Bandung.

Nisjar S., Karhi, 1997, Beberapa Catatan Tentang Good Governance, dalam Jurnal Administrasi dan Pembangunan, Jakarta.

Osborne, David dan Ted Gaebler, 1996, Mewirausahakan Birokrasi, PT. Pustaka Binaman Pressindo, Jakarta.

Santoso, Priyo Budi, 1993, Birokrasi Pemerintah Orde Baru Perspektif Kultural dan Struktural, Bina Aksara, Jakarta.

Siagian, Sondang P., 2000, Manajemen Abad 21, Bina Aksara, Jakarta.

Siagian, S.P. 2000. Teori Pengembangan Organisasi. Cetakan Ketiga, Bumi Aksara, Jakarta.

Syaukani, Afan Gaffar dan Ryaas Rasyid, 2002, Otonomi Daerah dalam Negara Kesatuan, Pustaka Pelajar, Yogkakarta.

Toha, Mifta, 2001, Good Governance : Telaah dari Dimensi Akuntabilitas dan Kontrol Birokrasi pada Era Desentralisasi dan Otonomi Daerah, Insan Cendekia, Surabaya.

Thoha, Miftah, 1995, Birokrasi Indonesia Dalam Era Globalisasi, Pusdiklat Pegawai Depdiknas, Sawangan, Bogor 
Vol.1 No.3. Oktober 2018. pp.1-13. Copyright@2018 PUBLICUHO Faculty of Social and Political Sciences Halu Oleo University, Kendari, Southeast Sulawesi, Indonesia. ISSN: 2460-058X | e-ISSN: 2621-1351. Open Access at: http://ojs.uho.ac.id/index.php/PUBLICUHO

(C) Jounal publiuho is licensed under a Creative Commons Attribution 4.0 International License, which permits unrestricted use, distribution, and reproduction in any medium, provided the original work is properly cited.

Tjokrowinoto, Moeljarto, 1990, Birokrasi Pembangunan Masyarakat, Makalah pada Seminar Nasional HIPPIS, Yogyakarta.

Widodo, Joko., 2001, Good Governance : Telaah dari Dimensi : Akuntabilitas dan Kontrol Birokrasi pada Era Desentralisasi dan Otonomi Daerah, Insan Cedekia, Surabaya.

Modul 1 Sosialisasi Sistem AKIP, 2001, Akuntabilitas dan Good Governance, LAN dan BPKP, Jakarta.

Undang-Undang Nomor 32 Tahun 2004 Tentang Pemerintahan Daerah.

Peraturan Pemerintah Nomor 41 Tahun 2007 Tentang Pedoman Organisasi Perangkat Daerah.

Peraturan Pemerintah Nomor 96 Tahun 2000 Tentang Wewenang Pengangkatan, Pemindahan dan Pemberhentian Pegawai Negeri Sipil.

Peraturan Pemerintah Nomor 99 Tahun 2000 Tentang Kenaikan Pangkat Pegawai Negeri Sipil.

Peraturan Pemerintah Nomor 12 Tahun 2002 Tentang Perubahan Atas Peraturan Pemerintah Nomor 99 Tahun 2000 Tentang Kenaikan Pangkat Pegawai Negeri Sipil.

Peraturan Pemerintah Nomor 84 Tahun 2000 tentang Pedoman Organisasi Perangkat Daerah Peraturan Pemerintah Nomor 41 Tahun 2007 Tentang Organisasi Perangkat Daerah 